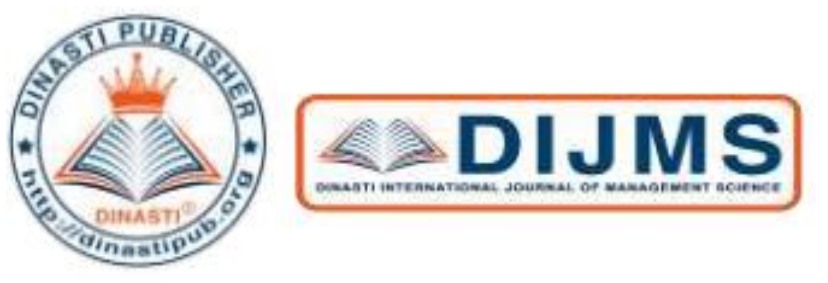

+6281387654578 (c)

081387654578 ()

https://dinastipub.org/DIJMS (4) editor@dinastipub.org@

\title{
RISK CULTURAL EVALUATION AS ORGANIZATIONAL CULTURE IN THE TAX SERVICE OFFICE
}

\section{Agus Bandiyono ${ }^{1}$, Lazuardi Widyanto Pratama ${ }^{2}$}

${ }^{1)}$ Polytechnic of State Finance STAN, Tangerang, Indonesia

2) Polytechnic of State Finance STAN, Tangerang, Indonesia

\begin{tabular}{|c|c|}
\hline $\begin{array}{l}\text { ARTICLE INFORM } \\
\text { Received: 08/10/2019 } \\
\text { Revised: } 13 / 10 / 2019 \\
\text { Issued: } 18 / 10 / 2019\end{array}$ & $\begin{array}{l}\text { Abstract: The objectives to be achieved in this study } \\
\text { are to evaluating risk management practices in the } \\
\text { form of a risk awareness culture and identifying factors } \\
\text { inhibiting the implementation of a risk awareness } \\
\text { culture at the Pondok Aren Primary Tax Service } \\
\text { Office. The research method used to obtain and } \\
\text { analyze data that can support this writing is a } \\
\text { qualitative method through interviews and document } \\
\text { collection through library research. The } \\
\text { implementation of the Risk Awareness Culture as a } \\
\text { whole has been following the implementation } \\
\text { guidelines namely Regulation of the Minister of } \\
\text { Finance No. 12 / PMK.09 / 2016 namely leadership } \\
\text { who is committed to considering risks in every } \\
\text { decision making, ongoing communication to all levels } \\
\text { of the organization regarding the importance of risk } \\
\text { management, respect for those who can manage risk } \\
\text { well, and integrate risk management in organizational } \\
\text { processes. However, in practice, the implementation of } \\
\text { the } 2016 \text { risk awareness culture at KPP Pratama } \\
\text { Pondok Aren encountered several obstacles. The } \\
\text { obstacles are in the form of a lack of reward (reward) } \\
\text { at the Pondok Aren Primary KPP and the Human } \\
\text { Resources aspect at Pondok Aren Pratama KPP. } \\
\text { Keywords: Risk Management, Public Sector } \\
\text { Management, Risk Culture, Organizational Culture, } \\
\text { Taxation. }\end{array}$ \\
\hline
\end{tabular}




\section{INTRODUCTION}

In carrying out its government, Indonesia has several forms of revenue for state revenue. One of the biggest forms of state revenue is tax revenue. Tax is one of the important state revenues used to finance government spending to realize public welfare.

However, in recent years, the realization of tax revenue has never reached the target stated in the State Budget (APBN). According to the 2015 Realization of the Revised State Budget (APBNP) Implementation Realization data, the realization of tax revenue is around $83 \%$ of the tax revenue target in the 2015 APBNP and according to data that the authors found on the news website (https://tirto.id), tax revenue per December 31, 2016, reached $81.54 \%$ of the tax revenue target in the 2016 APBNP. Not achieving the tax revenue target could result in disruption to the country's economy because most of the state's revenue in the APBN comes from tax revenue.

To avoid disrupting the country's economy, action is needed so that the realization of tax revenue can be used as well as possible to finance state expenditure. These actions are realized through risk management consisting of risk identification activities, risk analysis, and risk evaluation for not achieving tax revenue on the country's economy.

Concerning risk management, organizational culture is one of the factors that play a role in determining the level of success in implementing risk management in an organization. The main strategy in supporting the objectives of risk management is the establishment of a strong organizational culture by building a risk awareness culture between management and all employees. Risk awareness culture is important because it allows everyone in the organization to always care and be aware of risks in their daily activities (Hasyim, 2012: 29) The

Ministry of Finance as a ministry mandated to manage state finances implements a risk awareness culture through the Republic of Minister of Finance Regulation Indonesia Number 12 / PMK.09 / 2016 concerning the Implementation of Risk Management in the Ministry of Finance. The risk management process according to Regulation of the Minister of Finance Number 12 / PMK.09 / 2016 consists of developing a risk awareness culture, implementing a risk management process, and establishing a risk management structure.

The Directorate General of Tax (DGT) as an echelon I unit in the Ministry of Finance implements a risk awareness culture based on PMK No.12 / PMK.09 / 2016 concerning the Implementation of Risk Management within the Ministry of Finance. The risk awareness culture within the Directorate General of Taxes is inseparable from the main tasks and functions carried out by the Directorate General of Taxes. Following the mandate of the Minister of Finance Regulation No. 234 / PMK.01 / 2015 concerning the Organization and Work Procedure of the Ministry of Finance, the Directorate General of Taxation has to carry out the formulation and implementation of policies in the tax sector by statutory provisions. In carrying out these tasks, DGT carries out functions: formulation of policies in the field of taxation, implementation of policies in the field of taxation, preparation of norms, standards, procedures and criteria in the field of taxation, providing technical guidance and evaluation in the field of taxation, administration of the Directorate General of Taxes, and the implementation of other functions provided by the Minister of Finance.

The implementation of risk awareness culture in DGT is not only for the Head Office but applies to vertical agencies below, one of which is KPP Pratama. The risk awareness 
culture will encourage all employees at the KPP Pratama to pay more attention to risks in each decision making so that they can carry out their duties optimally as an agency that is given the task of collecting tax revenue.

Based on the descriptions described, the authors are interested in observing the implementation and evaluating a culture of risk awareness as an organizational culture according to PMK No.12 / PMK.09 / 2016 concerning the Risk Management Process in the Ministry of Finance.

The scope of this discussion is the evaluation of a risk awareness culture as a risk awareness culture at the Pondok Aren Tax Service Office according to Regulation of the Minister of Finance No. 12 / PMK.09 / 2016. To obtain the effectiveness and efficiency of writing, the issue to be discussed is the risk awareness culture at the Pondok Aren Primary Tax Office in 2016. The paper are objectives to be achieved by the author in this follows:

1) Evaluating risk management practices in the form of a risk awareness culture in the Pondok Aren Tax Office.

2) Identifying the factors inhibiting the implementation of a risk awareness culture at the Pondok Aren Primary Tax Service Office.

\section{LITERATURE REVIEW}

\section{Understanding Organizational Culture}

Understanding organizational culture according to Robbins (1996) is a system of shared meanings shared by its members that distinguishes these organizations from other organizations. A system of shared meanings is a key set of organizational values. Robbins characterizes the organization's culture as follows:

a. Innovation and risk-taking, namely the extent to which employees are encouraged to be innovative and dare to take risks;

b. Attention to detail, namely the extent to which employees are expected to show accuracy (accuracy), able to analyze, and full attention to work details;

c. Results orientation, which is the extent to which management focuses on results and not on the techniques and processes used to achieve these results;

d. People orientation, i.e. the extent to which management decisions have taken into account the impact of outcomes on people within the organization;

e. Team orientation, which is the extent to which work activities have been organized based on the team, not based on individuals;

f. Aggressiveness, which is the extent to which people are aggressive and competitive, rather than taking it easy; and

g. Stability, i.e. the extent to which organizational activities emphasize maintaining the status quo rather than growth.

Edgar H. Schein (2004) states organizational culture is a pattern of basic assumptions in which the group already knows that the assumption can solve problems in carrying out external adaptation and internal integration, and has been going well and stated as correct. The basic assumptions are togetherness which includes:

a. togetherness on something (shared-things), for example, uniforms;

b. the togetherness of words (shared-saying), for example, expressions, watchwords;

c. togetherness in actions (shared-doing), for example, community service, cooperation; 
d. togetherness in feelings (shared-feeling), for example, birthday greetings, condolences.

Stoner (1995) states that organizational culture as a cognitive framework that includes attitudes, values, norms of behavior, and expectations contributed by members of the organization. Davis (1984) states that organizational culture is a pattern of beliefs and organizational values that are understood, imbued, and practiced by organizations so that these patterns provide their meaning and form the basis for rules of behavior in organizations. Monde and Noe (1996) state that organizational culture is a system of shared values, beliefs, and habits in an organization that interacts with their formal structures to create norms of behavior. Organizational culture also includes values and standards that direct the behavior of organizational actors and determine the overall direction of the organization.

Hodge (1996) states that organizational culture is the construction of two levels of characteristics, namely organizational characteristics that are visible (observable) and(unseenunoservable). At the level observable, organizational culture covers various aspects of the organization such as architecture, uniforms, mindset, rules, myths, language and ceremonies carried out by the organization. At the level unobservable, organizational culture includes norms, shared values and the assumptions of the members of the organization to manage problems and circumstances. These two characteristics serve as the identity of the organization so that people from outside the organization will get to know the organization more easily from that identity.

Susanto (1997: 3) defines organizational culture values that guide human resources to deal with external problems and efforts to adjust integration into the company so that each member of the organization must understand the values that exist and as they must behave or behave. Glaser et al in Antonio (2010) argue that organizational culture is often described in a shared sense. Patterns of beliefs, symbols, rituals, and myths that develop over time that serves as an adhesive in uniting organizations. The various forms of organization or company, of course, have different cultures, this is natural because the organizational environment is different.

From this definition, it can be concluded that organizational culture is a system of values shared by members of the organization that serves as a means of uniting the organization and solving the organization that distinguishes an organization from other organizations.

\section{Ministry of Finance Organizational Culture}

As a government organization, the Ministry of Finance has an organizational culture program in carrying out its duties, principles, and functions. This cultural program distinguishes the Ministry of Finance from other ministries/organizations and the means to unite agencies within the Ministry of Finance.

Following the Letter of Director of KITSDA Number S-179 / PJ.11 / 2016 regarding the Guidelines for the Implementation of the Corporate Value Internalization Program (ICV), In House Training (IHT), and Leadership Development Program (LDP), the Ministry of Finance organizational culture consists of:

a. One Information Every Day is intended to encourage all Civil Servants and Prospective Civil Servants of the Ministry of Finance to seek positive information and share it (sharing) with other Ministry of Finance employees for shared knowledge. This culture is 
realized by preparing information delivery facilities such as sharing boards/boards information and update information regularly so that each employee gets information that can support the implementation of his work. To achieve the effectiveness of this cultural program, it is recommended that information delivery facilities be placed in each section/field/ sub directorate. Information that can be provided includes:

1) tax regulations;

2) staffing regulations;

3) information related to efforts to extract potential taxation; and

4) other general information.

b. Two Minutes Before the Schedule is intended to train, familiarize, and foster discipline among all Ministry of Finance employees by being present in the meeting room/place two minutes before the meeting starts on schedule to increase the effectiveness and efficiency of the meeting. This culture is realized by attending meetings at least two minutes before the meeting begins.

c. Three Greetings Every Day are intended to encourage all Ministry of Finance employees to be accustomed to providing the best service and to be polite by giving greetings by their time, namely good morning, good afternoon, and good afternoon. This culture is realized by getting used to providing the best service and being polite and polite, by giving greetings by the time, namely good morning, good afternoon and good afternoon.

d. Plan, Work, Monitor and Follow Up are intended so that all employees of the Ministry of Finance in carrying out their daily tasks apply the work ethic and management/organization principles properly by always making plans in advance, working to completion, monitoring and evaluating processes and results against targets and specifications and report the results, and follow up on the results to make repairs

e. concise, neat, clean, clean and diligentintended to foster awareness, confidence, and concern of employees of the Ministry of Finance of the importance of structuring office space and working documents that are concise, neat and clean / clean through care performed routinely to create a comfortable work environment to improve work ethic and work morale.

\section{Organizational Culture of the Directorate General of Tax (DGT)}

Organizational culture at DGT is an internalization Corporate Value (ICV) program organized to shape organizational culture as a form of implementing organizational culture within the Ministry of Finance. According to Kisda Director Circular Letter No S-179 / PJ.11 / 2016, DGT organizational culture includes:

a. Morning Prayer is a DGT culture where officials/employees always start work every day by praying to Almighty God to provide help in carrying out daily work and to achieve tax revenue targets. This culture is realized by doing morning prayers together every morning and can be done through loudspeakers or by gathering together in their respective rooms.

b. Shame Being Late is a DGT culture where employees/officials feel ashamed if they are late to attend work (after 07.30 local times), even though the employee/official can change the time of delay or make a permit/notification. The culture of Shame Too Late is realized by writing on the honesty board for every official/employee who is late to attend work. 
c. Care Smiles, Greetings and Sapa (Caring for Whom) is a DGT culture where employees/officials always care and are friendly to taxpayers, fellow employees, and everyone in the office environment.

d. Effective Meetings is a DGT culture where officials/employees always pay attention to effective meeting guidelines in every meeting.

e. DGT Fitter is a DGT culture where officials/employees always maintain excellent health conditions by exercising regularly at the weekly hour every Friday from 07.35 to 08.05 local time.

f. Polite in Social Media is a DGT culture where officials/employees always uphold the DGT Employee Code of Ethics in every use of social media. In implementing this culture, officials/employees are expected to:

1) respect the religion, beliefs, culture, and customs of others;

2) use polite words;

3) protect and secure data/information owned by DGT;

4) utilizing social media for positive things while maintaining the norm of decency and the image and dignity of the Directorate General of Taxes

g. 5 Minutes Before Returning is a DGT culture where DGT officials/employees always spend 5 minutes before leaving work to ensure that the worktable is left in a neat and tidy condition clean. This culture is realized by doing the following:

1) tidying the files on the table and filing them well;

2) destroying the concept of unused service manuscripts;

3) throwing trash around the work table to the trash;

4) tidying up other items on the table;

5) turn off computers, printers, scanners, and other electronic equipment.

\section{Understanding Risk Awareness Culture as Part of Risk Management}

Understanding risk management according to Nurharyanto $(2009,2)$ is a systematic and ongoing process designed and carried out by management at all levels and all organizational personnel to provide adequate confidence that all risks that potentially hinder the achievement the objectives have been identified and managed in such a way that the intended risk is within acceptable limits. The main objectives of risk management according to Nurharyanto are as follows:

a. Ensuring that existing risks have been identified/recognized and assessed as significant and that an action plan has been made to minimize the impact and likelihood of such risks;

b. Ensuring that the action plan has been implemented effectively;

c. Providing recommendations to management regarding the risks that might occur as well as recommendations for handling them.

Concerning risk management, organizational culture is one of the factors that play a role in determining the level of success in implementing risk management in an organization. The main strategy in supporting the objectives of risk management is the establishment of a strong organizational culture by building a risk awareness culture between management and all employees. Risk awareness culture is important because it allows everyone in the organization to always care and be aware of risks in their daily activities (Hasyim, 2012: 29).. 


\section{RESEARCH METHODS}

The research method used to obtain and analyze data that can support this writing is a qualitative method through interviews and document collection through library research.

1) Library Research Methods The

a library research method is carried out by studying several kinds of literature on risk awareness culture to obtain a theoretical basis for the issues to be discussed in this study.

2) Field Study

Method This method aims to collect data that supports this writing by surveying research objects directly to find out the actual conditions in the field. This includes interviews with the Head of Section (Kasi) of Examination to find out the culture of risk awareness in KPP Pratama Pondok Aren.

\section{FINDINGS AND DISCUSSION}

\section{Evaluation of Risk-Conscious Culture as Organizational Culture at KPP Pondok Aren}

Organizational culture according to Robbin (1996) is a shared value system adopted by members that distinguish an organization from other organizations. This shared value system is a set of keys that are held in high esteem by the organization. Organizational culture is concerned with how employees understand the cultural characteristics of an organization and is not related to whether employees like those characteristics or not.

One form of organizational culture is a risk awareness culture that is part of risk management. Risk awareness culture is included in the organizational culture because there is a shared value system adopted by all members in an organization that is awareness to minimize risks that can hinder the achievement of an organization's goals.

Pratama Pondok Aren Tax Office (KPP) as one of the vertical agencies of the Directorate General of Tax (DJP) within the scope of the Regional Office of the Banten DGT runs a risk awareness culture based on Minister of Finance Regulation Number 12 / PMK.09 / 2016 concerning Management Application Risks in the Ministry of Finance applicable from 1 July 2016 to 31 December 2016. The risk awareness culture as referred to in PMK No. 12 / PMK.09 / 2016 is realized by understanding and managing risk as part of every decision making process at all levels of the organization in the form :

a. Leadership that commits to consider risk in every decision making

Attachment I PMK No.12 / PMK.09 / 2016 regarding general guidelines for risk management explains that leaders must commit to risk in every decision making. This commitment is demonstrated by, among others, ensuring that organizational resources are sufficiently available for the implementation of risk management. The organization's resources include funds, human resources, and supporting tools for implementing risk management such as organizational structure, work procedures, policies, guidelines and strategies for implementing risk management.

Concerning organizational culture, leadership according to Robbin and Judge (2013) is one way to form a strong organizational culture that is with the behavior of leaders who act as role models that encourage employees to identify themselves to internalize the beliefs, values, and assumptions of the leaders concerned. 
From the results of interviews conducted by the author, the Head of Section (Kasi) Examination as the party conducting the administration of risk management according to PMK No. 12 / PMK.09 / 2016 states that to achieve organizational goals, some steps must be taken. Each of these steps has risks that need to be considered in making a decision. Good decisions, one of which is a decision that has considered risks in the process of making it.

Implementation of the leadership provisions that consider risks in every decision making, one of which is the provisions of the meeting held at Pondok Aren KPP. The process of considering risks does not always occur in every meeting, but rather emphasizes the minutes of the meeting. Therefore, according to the authors, the provisions regarding leadership that are committed to considering risk in every decision making as a culture of risk awareness in KPP Pratama Pondok Aren have not become a strong organizational culture because it is not always applied in every meeting that is held.

b. Ongoing communication to all levels of the organization regarding the importance of risk management

Appendix I PMK No.12 / PMK.09 / 2016 regarding general guidelines for risk management explains that communication about the importance of risk management must be carried out on an ongoing basis to all employees, both in decision making meetings and in the form of meetings to carry out the risk management process. Profiles and risk maps that have been prepared must be communicated to all members of the organization. The risk mitigation plan that has been prepared must also be communicated to all organizations to get support and ensure the effectiveness of its implementation.

Concerning organizational culture, communication is one means to convey the values and rules that apply in an organization so that it is expected to create a strong organizational culture. Robbins and Judge (2013) state that what management can do to create a strong organizational culture is by communicating the core values of the organization and various ethical rules that are expected to be obeyed by all employees.

According to the results of interviews conducted by the author, the form of communication regarding risk management is done through meetings between the Head of Office and Section Head (Kasi), and through socialization to all employees at the KPP Pratama Pondok Aren through In House Training (IHT) which is held once a year. Information regarding risk management communicated by the Head of Examination as the administrator according to PMK No. 12 / PMK.09 / 2016 is a risk mitigation plan that has been prepared, and risks that need special attention are fraud risk (risk) and operational risk while profile and risk map is not communicated to all employees at KPP Prat Aren Pondok Aren. According to the Head of Examination, the reason for not submitting a profile and risk map to all employees is the profile and risk map contains details while there are still employees who do not understand the concept of risk management so that it will cause ineffectiveness in conducting such communication if the profile and risk map are communicated. to all employees.

The method used by the Kasi Examination to check the level of understanding of all employees regarding the risk awareness culture is to test how the employee understands the job description related to the work he is doing. According to KMK No. 1555 / KM.01 / 2011 concerning the Description of Structural Positions in the Directorate General of Tax's 
Vertical Office Environment, the job description is a detailed and complete description of position information. The structure of the job description itself consists of:

1) Name of Position.

2) Job Overview.

3) The intention of the official position.

4) Description of Duties and Activities.

5) Work Materials.

6) Work equipment.

7) Work result.

8) Authority.

9) Responsible.

10) Job Dimension.

11) Work relationship.

12) Problems and Challenges of Position.

13) Risk of Danger.

14) Job Requirements.

15) Position in the Organization.

If the employee understands job descriptions related to work, the employee has implemented a risk awareness culture in his work because one of the job description structures contains hazard risks related to work. Conversely, employees who do not understand job descriptions properly, the employee has not implemented a risk awareness culture in his work. The Head of Inspection shall test the employee's understanding of the job description not every time if only necessary. Routine testing is carried out by the head of the relevant section as the executive coordinator. Example: Head of Service Section as coordinator of the service section.

According to the results of interviews conducted by the author, the implementation of ongoing communication about the importance of risk management has been carried out well because all employees have understood job descriptions related to their work. An understanding of job descriptions raises a conscious and caring attitude towards risks associated with his work.

Appreciation for those who can manage risk well. Appendix I PMK No.12 / PMK.09 / 2016 regarding the general guidelines for risk management explains thatsystems rewardmust be designed to reward those who manage risk well. Performance appraisal must consider the application of risk management that has been carried out by the organization. The granting of an award system must be equal and commensurate with the successful application of risk management by an organization.

Regarding organizational culture, Robbins (1996) suggests ten characteristics of organizational culture one of which is the existence of a reward system. The existence of an award system will be seen in the culture of the organization with the allocation of rewards (salary increases, promotions) based on the criteria of the work results of employees who have been determined.

According to the interview conducted by the author, the provision of respect for those who can manage risk properly has not been implemented properly at the KPP Pratama Pondok Aren. This can be seen from the 19 risk designs that will be mitigated, 16 risks have 
been well managed while 3 other risks have not been managed properly. Of the 19 draft risks to be mitigated, risks that have a large impact, namely fraud risk and operational risk have been well managed at Pondok Aren KPP. The risk determination criteria have been managed well seen from whether the results achieved are by the organizational goals that have been prepared by the Head of Inspection as the party that carries out the administration in the risk mitigation design. However, in KPP Pratama Pondok Aren there is no rule to reward) for the section that has managed risk well and there is no punishment or the section that has not managed the risk well. That is why there are still risks that have not been well managed so that the risk awareness culture has not been implemented properly at the Pondok Aren Primary Tax Office.

According to the results of interviews conducted by the author, the provision of giving awards to those who can manage risk properly has not been implemented in the Pondok Aren Primary Tax Office because there is no discourse from the Primary Tax Office to implement the provisions reward and punishment. The absence of systems reward and punishment related to risk awareness culture does not affect the implementation of risk awareness culture in the Pondok Aren Primary Tax Office, this is evidenced by the success of the Pondok Aren Tax Office managing 16 risks well out of a total of 19 risks in the risk mitigation design.

\section{c. Integrating risk management in organizational processes}

Appendix I PMK No.12 / PMK.09 / 2016 regarding general guidelines for risk management explains that the integration of risk management into organizational processes is carried out in stages. This integration can be initiated by considering and harmonizing the risk management process in the organization's performance management system. Besides, the mitigation measures designed can serve as a reliable source for formulating strategic initiatives.

Regarding organizational culture, generally, the organizational culture that applies in an organization is identical to the organization's business processes. According to Robbins (1996), a strong organizational culture is a culture that is characterized by the core values of organizations that are strongly held, well-organized, and widely shared. Besides, a strong organizational culture can be characterized by the presence of parties in the organizational structure that monitors the implementation of organizational culture. If an organization has a strong organizational culture, performance management in the organization will run effectively because every party in the organization has correctly understood the core values of the organization.

The form of the implementation of the provisions for the integration of risk management in organizational processes at KPP Pratama Pondok Aren can be seen in several aspects. The first aspect can be seen from the formation of the organizational structure related to risk management in KPP Pratama Pondok Aren which refers to the Minister of Finance Regulation No. 12 / PMK.09 / 2016 concerning the Implementation of Risk Management in the Ministry of Finance Environment which consists of: 1) Head of the Inspection Section as the administrator; 2) All employees at the Pondok Aren Primary Tax Office as the executor; 3) Section Chief as the implementing coordinator; 4) Head of General and Internal Compliance Subdivision as the risk monitor. The parties mentioned above carry out and 
ensure that a risk awareness culture has been implemented at the Pondok Aren Primary Tax Office.

The second aspect can be seen that risk awareness culture becomes an integrated part of the values shared by Pondok Aren KPP. As an institution within the Ministry of Finance, the values shared by the KPP Pratama are those of the Ministry of Finance. The Ministry of Finance's values and their relation to a risk awareness culture:

1) Integrity

Integrity value means thinking, saying, behaving, and acting properly and correctly and upholding the code of ethics and moral principles. If all employees can apply the value of integrity in their work, the employee will emerge an attitude of not cheating (fraud) in carrying out his work so that indirectly embedded culture of risk awareness in employees.

2) Professionalism

The value of professionalism means working thoroughly and accurately on the basis of the best competencies with full responsibility and high commitment. If all employees can apply the value of professionalism in their work, the employee will work with care based on his expertise and knowledge so that the employee can distinguish things that should be done and which should not be done. This attitude of working with heart can reduce fraudulent behavior so that it will be embedded in a risk awareness culture in carrying out its work that is aware of the risk of fraud.

3) Synergy

The value of synergy means building and ensuring productive internal cooperative relationships and harmonious partnerships with stakeholders to produce useful and quality work. If the value of synergy is applied by all employees in the Pondok Aren KPP Primary, all employees will strive to always find and implement the best solutions in carrying out work and have an attitude of mutual trust and respect. Implementation of the value of synergy in the Pondok Aren KPP will reduce the risk of decreasing public trust so that the application of the value of synergy in employees will reduce operational risks that might occur if done by an employee. Therefore, the value of synergy will lead to a culture of risk awareness in employees.

4) Service

The value of service means providing services that meet stakeholder satisfaction which is done wholeheartedly, transparently, quickly, accurately, and safely. If the service value is applied by all employees at the Pondok Aren Primary Tax Office, all employees will try to be proactive and responsive to taxpayers. Proactive attitude and employee responsiveness will reduce the risk of declining community trust so that the application of service values in employees will lead to a culture of risk awareness in the employee that is aware of the risk of reputation decline.

5) Perfection

The value of perfection means to always make improvements in all fields to be and provide the best. If the value of perfection is applied by all employees at the Pondok Aren Primary Tax Office, the employee will strive to continuously make improvements in the operational systems in the Pondok Aren Primary Tax Office so that the operational system is a system that is in accordance with the times and does not bother the 
Obligatory Tax. The attitude to continually make improvements indirectly will lead to a culture of risk awareness in employees that is aware of operational risks. Example: how to submit SPT at this time can be through electronic systems such as e-SPT and e-Filling. The existence of this system can reduce the risk of Taxpayer data that has not been recorded if the Taxpayer submits manually because the submission of the SPT with an electronic system will be recorded directly in the Pondok Aren KPP computer system.

According to the results of the interviews conducted, the provisions on the integration of risk management in the organizational process at KPP Pratama Pondok Aren have been implemented well. This is evidenced by the implementation of the organizational structure at the KPP related to risk awareness culture at KPP Pratama Pondok Aren in accordance with PMK No. 12 / PMK.09 / 2016 concerning the Implementation of Risk Management in the Ministry of Finance and a risk awareness culture that is an integrated part of the values Ministry of Finance which is held at Pondok Aren KPP Pratama.

\section{Inhibiting Factors of Risk Conscious Culture at KPP Pratama Pondok Aren}

Attachment I of PMK No.12 / PMK.09 / 2016 concerning general guidelines for risk management explains the level of maturity of risk awareness culture which can be proven by assessment parameters: a. Leadership commitment and understanding of the implementation of Risk Management is low; $b$. The risk management process is carried out incompletely and identification is not comprehensive; c. The percentage of mitigation implemented and the success of reducing the low risk level; $d$. The success of achieving strategic goals is low.

Based on these assessment parameters, the risk awareness culture in the Pondok Aren Primary Tax Office has exceeded the assessment parameters contained in Appendix I of PMK Number 12 / PMK.09 / 2016. However, obstacles are still found in the implementation of a risk-conscious culture so that there are several criteria in the assessment parameters for risk management maturity that results are less satisfactory.

The author groups the obstacles that occur in the application of risk awareness culture in KPP Pratama Pondok Aren into several aspects, including the lack of appreciation and aspects of Human Resources at KPP Pratama Pondok Aren.

a. Lack of Rewards (reward) at Pondok Aren Primary Tax Office

The lack of appreciation aspect is one of the obstacles that the implementation of risk awareness culture in KPP Pratama Pondok Aren. Lack of appreciation for those who have managed risk well and there is no punishment for those who have not been able to manage risk well. According to Mr. Asep, there is currently no discourse to provide rewards for those who manage risk well and punishment for those who have not managed risk well. Meanwhile, according to the Internal Compliance Officer the reward and punishment system is not implemented because risk-aware culture is a culture that must be carried out jointly by all employees at the Pondok Aren Primary Tax Office so that if there are risks that have not been properly managed, it is a shared responsibility all employees at KPP Pratama Pondok Aren.

b. Aspects of Human Resources at KPP Pratama Pondok Aren

Another aspect is the low understanding of employees at the KPP Pratama Pondok Aren regarding the risk awareness culture itself. The low understanding of risk awareness culture can be seen from the lack of employees who are aware that the education and 
training (training) that they participate in or the socialization organized by KPP Pondok Aren is intended so that each employee knows better the risks associated with his work so that the employee can be more careful and care in carrying out their work.

However, the low understanding of employees about risk awareness culture is overcome by the large number of employees who understand job descriptions. Understanding of the job description makes a risk awareness culture can be implemented well in the Pondok Aren Primary Tax Office. This is because one of the job descriptions contains risks related to his work so that if an employee understands his job description well, risks in his work can be handled properly by the employee

\section{CONCLUSION AND SUGESTION Conclusions}

Based on research, interviews, and discussions by the author of the 2016 Risk Awareness Culture at the Pondok Aren Primary Tax Service Office, several conclusions can be drawn as follows:

1) Evaluation of Risk Awareness Culture as Organizational Culture at KPP Pratama Pondok Aren.

a. The implementation of the 2016 Risk Conscious Culture at Pondok Aren Pratama KPP as a whole has been in accordance with the implementation guidelines namely Regulation of the Minister of Finance No. 12 / PMK.09 / 2016 concerning Application of Risk Management in the Ministry of Finance Environment, namely leadership who has a commitment to consider risk in every decision making, ongoing communication to all levels of the organization regarding the importance of risk management, appreciation for those who can manage risk well, and the integration of risk management in organizational processes.

b. The provisions regarding leadership that have a commitment to consider risks in every decision making, and rewards for those who can manage risks well have not been implemented properly in accordance with Attachment I to the Minister of Finance Regulation Number 12 / PMK.09 / 2016. The main points that have not been implemented well are in the policy to consider risks, which are not always carried out at every meeting held and there is no system of rewards for those who can manage risks properly.

2) Inhibiting Factors of Risk Conscious Culture at KPP Pratama Pondok Aren

Implementation of Risk Awareness Culture in 2016 at Pondok Aren Primary Tax Office based on the assessment parameters as listed in Appendix I PMK Number 12 / PMK.03 / 2016 concerning general guidelines for risk management has fulfilled the risk awareness culture criteria.

However, in practice, the implementation of the 2016 risk awareness culture at KPP Pratama Pondok Aren encountered several obstacles. The obstacles are in the form of lack of reward (reward) at the Pondok Aren Primary KPP and the Human Resources aspect at Pondok Aren Pratama KPP. Various efforts have been made by KPP Pratama Pondok Aren to overcome these obstacles such as:

a. To overcome the lack of reward (reward), Pondok Aren Primary KPP seeks to instill awareness to all employees that a risk-aware culture is a culture that must be shared 
by all employees at the Pondok Aren KPP because by implementing a risk awareness culture in employees at the Pondok Aren KPP Pratama, risks that can hinder the achievement of organizational goals can be minimized.

b. To overcome obstacles from the aspect of human resources at the Pondok Aren KPP Primary, Pondok Aren Pratama KPP seeks to conduct In House Training (IHT), and outreach to all employees so that employees are expected to know more about the risks associated with their work.

\section{Suggestion}

In order to optimize the implementation of risk awareness culture at the Pondok Aren Primary Tax Office, improvement or attention is required in the case of:

a. Continuous communication about the importance of risk management at the Pondok Aren Primary Tax Office needs to be further enhanced and carried out every month or every certain period of time. The communication that is more often useful for employee understanding of the importance of implementing a risk awareness culture both related to their work and risks in the KPP Pratama Pondok Aren.

b. The efforts made by the Pondok Aren KPP Pratama in overcoming existing obstacles need to be maintained and improved so that the risk awareness culture in the Pondok Aren Pratama KPP can be implemented as a whole by the employees.

\section{REFERENCES}

\section{Books and Journal}

Davis. 1984. Managing Corporate Culture. Cambridge : Belinger

Hasyim, Faisal Ali. 2012. "Implementasi Manajemen Risiko untuk Mewujudkan Good Governance”. Jurnal. Bandung : Universitas Padjajaran.

Hodge. 1996. Organizational Strategy, 5th Ed. Prentice Hall. Englewood Cliffs, New Jersey

Noe dan Mondy. 1996. Human Resource Management. 6th Edition. New Jersey : Prentice Hall.

Nurharyanto. 2009. "Penciptaan Budaya Peduli Risiko (Risk Awareness) untuk Mendukung Implementasi Manajemen Risiko Sektor Publik". Makalah. Jakarta : BPKP.

Robbins, Stephen P. 1996. Perilaku Organisasi: Konsep, kontroversi dan aplikasi. Jilid 1 dan 2. Jakarta: PT. Prenhallindo

Robbins, Stephen P dan Timothy A. Judge. 2013. Organizational Behavior. New Jersey: Pearson Education, Inc.

Saroh, Mutaya. 2017. Penerimaan Negara Sebesar 81,54 persen dari Target APBN 2016. (Online). (https://tirto.id/penerimaan-negara-sebesar-8154-persen-dari-target-apbn2016-cdHp. Diakses 04 Mei 2017).

Schein, Edgar H. 2004. Organizational Culture and Leadership Third Edition. USA : Jossey Bass

Susanto. 1997. Budaya Perusahaan. Jakarta : PT Elex Media Komputindo.

Sumarwanto, Antonio. 2010. Analisis Pengembangan. (Online). (http://lib.ui.ac.id/file?file=digital/135958-T\%2028091 Analisis\%20pengembanganLiteratur.pdf. Diakses 17 Mei 2017). 
Stoner et. al. 1995. Management. 6th Ed. New Jersey : Prentice Hall

\section{Regulations}

Republik Indonesia. 2011. Keputusan Menteri Keuangan Republik Indonesia Nomor 312/KMK.01/2011 tentang Nilai-Nilai Kementerian Keuangan. Jakarta : Sekretariat Negara.

Republik Indonesia. 2013. Keputusan Menteri Keuangan Republik Indonesia Nomor 127/KMK.01/2013 tentang Program Budaya di Lingkungan Kementerian Keuangan Tahun 2013. Jakarta : Sekretariat Negara.

Republik Indonesia. 2014. Peraturan Menteri Keuangan Republik Indonesia Nomor 206.2/ PMK.01/2014 tentang Organisasi dan Tata Kerja Instansi Vertikal Direktorat Jenderal Pajak . Jakarta : Sekretariat Negara.

Republik Indonesia. 2015. Peraturan Menteri Keuangan Republik Indonesia Nomor 234/ PMK.01/2015 tentang Organisasi dan Tata Kerja Kementerian Keuangan . Jakarta : Sekretariat Negara.

Republik Indonesia. 2016. Peraturan Menteri Keuangan Republik Indonesia Nomor 12/ PMK.09/2016 tentang Penerapan Manajemen Risiko di Lingkungan Kementerian Keuangan . Jakarta : Sekretariat Negara.

Republik Indonesia. 2016. Surat Direktur KITSDA Nomor S-179/PJ.11/2016 tentang Petunjuk Pelaksanaan Program Internalisasi Corporate Value (ICV), In House Training (IHT), dan Leadership Depelovement Program (LDP). Jakarta : Sekretariat Negara.

Republik Indonesia. 2016. Siaran Pers Nomor 01/KLI/2016 tentang Realisasi Pelaksanaan APBNP Tahun 2015. Jakarta : Sekretariat Jenderal Kementerian Keuangan. 